- RAM, REV. ADM. MACKENZIE, 17(3) • SÃO PAULO, SP • MAIO/JUN. 2016 • ISSN 1518-6776 (impresso) • ISSN 1678-6971 (on-line) • http://dx.doi.org/10.1590/1678-69712016/administracao.v17n3p183-211. Submissão: 11 set. 2015. Aceitação: 28 jan. 2016. Sistema de avaliação: às cegas dupla (double blind review). UNIVERSIDADE PRESBITERIANA MACKENZIE. Silvio Popadiuk (Ed.), Claudia Cristina Bitencourt (Ed. Seção), p. 183-211.

\title{
GREEN MARKETING AS A MEDIATOR \\ BETWEEN SUPPLY CHAIN MANAGEMENT AND ORGANIZATIONAL PERFORMANCE
}

\section{EDNEI ROGÉRIO DE SOUZA ZAMPESE}

Doctor in Business Administration from the Graduate Program of Business Administration at the Universidade Presbiteriana Mackenzie (UPM).

Director of Customer and Planning - Consumer Market at Editora Globo. Avenida Nove de Julho, 5229, Jardim Paulista, São Paulo - SP - Brasil - CEP 01406-200

E-mail: ednei.rogerio@zampese.com.br

ROBERTO GIRO MOORI

Doctor in Production Engineering from the Politechnical School, Department of Production Engineering at the Universidade de São Paulo (USP).

Professor for the Graduate Program in Business Administration at the Universidade Presbiteriana Mackenzie (UPM). Rua da Consolação, 896, Prédio 45, Consolação, São Paulo - SP - Brasil - CEP 01302-907

E-mail: roberto.moori@mackenzie.br

\section{ADILSON CALDEIRA}

Doctor in Business Administration from the Graduate Program in Business Administration at the Universidade Presbiteriana Mackenzie (UPM).

Professor for the Professional Master's Program in Administration of Business Development at the Universidade Presbiteriana Mackenzie (UPM).

Rua da Consolação, 896, Prédio 45, Consolação, São Paulo - SP - Brasil - CEP 01302-907

E-mail: adilson.caldeirai@mackenzie.br

Este artigo pode ser copiado, distribuído, exibido, transmitido ou adaptado desde que citados, de forma clara e explícita, o nome da revista, a edição, o ano e as páginas nas quais o artigo foi publicado originalmente, mas sem sugerir que a RAM endosse a reutilização do artigo. Esse termo de licenciamento deve ser explicitado para os casos de reutilização ou distribuição para terceiros. Não é permitido o uso para fins comerciais. 


\section{ABSTRACT}

Purpose: The study aims to explore and describe the mediation of green marketing in the relationship between supply chain management and corporate performance. Originality/gap/relevance/implications: The prior intention was to fill an epistemological gap about green marketing. The presence of green marketing in regression decreases the magnitude of the relationship between supply chain management and performance in Brazilian construction companies.

Key methodological aspects: The study was carried out using quantitative method with exploratory and descriptive purposes. An exploratory research was conducted through in-depth interviews with ten managers working in the construction business. A descriptive survey involved the application of a questionnaire answered by a sample of 133 respondents. Data was analyzed using descriptive statistics, linear regression and structural equation modeling.

Summary of key results: Data showed that green marketing mediates, in part, the relationship between supply chain management and corporate performance. Key considerations/conclusions: As theoretical implications, the study reinforces positive correlations between the constructs used in the surveyed sector. It resorted to models previously developed that, combined, could be reproduced or falsified, in order to obtain, finally, convergent measurement models. As a practical application, it identified the involvement of employees in environmental issues, missions and visions with explicit statements on energy and water saving and green marketing initiatives to improve the corporate image, such as obtaining environmental certifications. In conclusion, it appears that the civil construction companies have room to improve the communication and image to stimulate both the supply and consumption of green products.

\section{KEYWORDS}

Green marketing. Organizational performance. Supply chain management. Green supply chain. Supply chain in construction. 


\section{INTRODUCTION}

Under the growing pressure of demand for goods and services, determined by global population multiplication, companies are at risk of causing damage to ecosystems. Ozone layer destruction, climate change and accumulation of waste pollutants, which affect agricultural production, quality of life and tourism activities, are examples of those effects (Dahlstrom, 20II). Companies that produce goods and provide services (King, Felin, \& Whetten, 2009), considered the main responsible for environmental damages, face the challenge of adopting cleaner or "green" practices (Dahlstrom, 20II).

The adoption of green practices, whether motivated by external regulatory pressures or internal proactivity, pervades decisions relating to the management of the supply chain by companies located in both downstream and upstream position in it. (Bowen, Cousins, Lamming, \& Faruk, 200I). Green supply chain management (GSCM) aims to achieve improvements in many ways of business performance: economic performance (Alvarez Gil, Jimenez, \& Lorente, 200I), environmental and financial performances (Chien \& Shih, 2007), environmental performance (Kim, Youn, \& Roh, 20II), organizational performance (Shang, Lu, \& Li, 20IO), ecological and economic performances (Zhu, Sarkis, \& Geng, 2005).

The market behavior itself, which leans towards an increase in both consumer demand and consumer awareness, encourages companies to create and deliver products considered "green" (Murphy, Graber, \& Stewart, 2010). The use of green marketing to facilitate the consumption, production, distribution, promotion and claim of products in a manner that is sensitive or responsive to ecological problems (Dahlstrom, 20II) can influence the achievement of practical results concerning profitability, marketing performance, cost reduction (Fraj, Martínez, \& Matute, 20II) and new product launches (Baker \& Sinkula, 2005), meaning improvements in the company's performance.

Construction supply chains have peculiar characteristics, such as high fragmentation, project vision, instability, high dependence on work force and high levels of uncertainty (Koskela, I992). In this sector, most projects are carried out with production and assembly on-site and rely on efficient delivery logistics (Azambuja \& O'Brien, 2009). According to the Brazilian Chamber of Construction Industry (Câmara Brasileira da Indústria da Construção-CBIC), the water and energy savings with a consequent reduction in building management costs and less environmental impact represent hubs/cores of sustainable buildings (Vaz, 20I4). Other actions toward greening supply chains can 
be seen in the importance of sustainability certifications (Yudelson, 2006), such as LEED - Leadership in Energy and Environmental Design - from USA, the AQUA process - High Environmental Quality, a French certification (Coelho, 20I0), and the funding for sustainable projects (Banco Nacional de Desenvolvimento Econômico e Social - BNDES, 2015).

Within this context, the following research issue becomes relevant: is green marketing a mediating factor in the relationship between GSCM and organizational performance?

The objective was to assess the magnitude and statistical significance of green marketing, as an indirect way of the relationship between GSCM and organizational performance.

The article is structured as follows: after this introduction, we present a literature review, the research model and hypotheses, followed by the methodological procedures, analysis of data and results. Finally, the final considerations display a discussion about implications and alternative paths for further researches.

\section{THEORETICAL REFERENCES, MODEL AND HIPOTHESYS}

According to Zhu et al. (2005), GSCM may have a direct effect on organizational performance. Green marketing specific actions can be of great assistance to improve this performance (Shang et al., 2010). In this case, it is assumed that the green marketing plays a mediating function through which GSCM indirectly may affect the organizational performance.

To test statistically the mediating effect of green marketing in the relationship between GSCM and OP (Organizational Performance), a four-hypothesis-theoretical-model was prepared as shown in Figure I. 


\section{FIGURE I}

REPRESENTATION OF THE INFLUENCE OF GM IN THE RELATIONSHIP BETWEEN GSCM AND OP
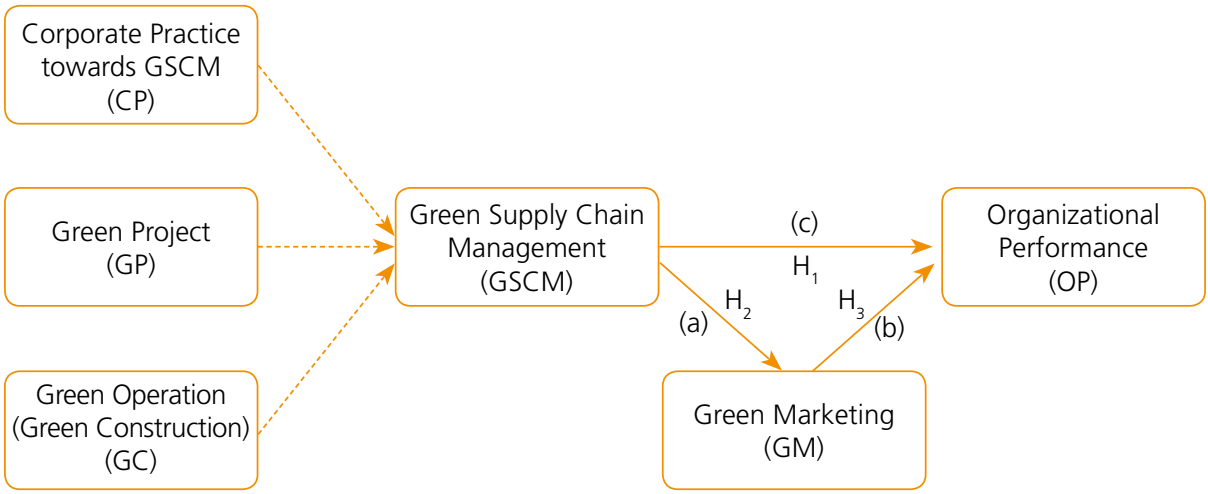

(a)

(b)

Green Marketing

(GM)

Note: mediation, according to Iacobucci, Saldanha and Deng (2007):

I. If $\mathrm{H}_{2}$ or $\mathrm{H}_{3}$, or both hypotheses are not statistically significant - then GM does not mediate the relationship between GSCM and OP $\rightarrow$ rejects to $\mathrm{H}_{4}$.

2. If $\mathrm{H}_{2}$ and $\mathrm{H}_{3}$ are statistically significant - then GM mediates the relationship between GSCM and $\mathrm{OP} \rightarrow$ is accepted $\mathrm{H}_{4}$.

2.I) Apply the $z$ Sobel test to see if mediation is partial or total.

a. if $\mathrm{z}$ is statistically significant and $\mathrm{HI}$ is not - then the mediation is complete.

b. if $\mathrm{z}$ is not statistically significant, but $\mathrm{H}$ is - then mediation is partial.

c. if neither $\mathrm{z}$ nor $\mathrm{HI}$ are statistically significant - then mediation is partial.

Source: Elaborated by the authors.

The following sections present conceptual foundations that support this adopted theoretical model.

\subsection{GREEN SUPPLY CHAIN MANAGEMENT (GSCM) AND ORGANIZATIONAL PERFORMANCE (OP)}

The study of Supply Chain Management (SCM) started in the I980's (Burgess, Singh, \& Koroglu, 2006) and represents the essential concern to integrate critical business processes to add value to consumers and other stakeholders (Lambert, I993).

Green Supply Chain Management (GSCM) covers the functions of SCM and extends to Reverse Logistics (Srivastava, 2007). The addition of the term "green" 
to SCM includes the influence and the relationship with the environment. Therefore, GSCM has its roots in SCM literature, together with the environmental management literature.

Srivastava (2007), in a review of the literature between I980 and 2005, divides the academic texts on GSCM into three main areas: the importance of GSCM corporate practices, Green Design and Green Operation. The area that discusses the importance of corporate practices regarding GSCM concerns competitive initiatives focused on saving resources, eliminating waste and improving productivity. That practices may be considered reactive if related to the compliance with laws and regulations, or proactive, when dedicated to anticipating the law and seeking added value through the integration of environmental activities in the scope of business strategies.

Green Design refers to environmentally conscious design, involving substitution of potentially hazardous materials and processes, as well as life cycle analysis, consisting of the global monitoring of raw materials, from extraction to final disposal, and the flow of energy and materials in the environment. Green Operation is divided into green manufacturing (reduction in the use of materials, recycling, remanufacturing, inventory management and production planning), reverse logistics and network design (obtaining, inspection, pre-processing and distribution of materials for recycling and reuse) and waste management (reduction of polluting sources, pollution prevention, and disposal) (Srivastava, 2007).

Other actions toward the "greening" of the supply chain are sustainability certifications for construction market (Yudelson, 2006). The two most relevant are Leadership in Energy and Environmental Design (LEED) from the USA, and Haute Qualité Environnementale (Alta Qualidade Ambiental [Aqua], from France, a translation of High Environmental Quality [HQE]) (Coelho, 20IO).

Corporate GSCM practices, according to Chakraborty (20I0), have been sources of cost efficiency and profitability, not only as a way of increasing sales and market share, reducing rework, encouraging the reverse logistics and optimizing resources, but as a way of developing new market opportunities with higher profit margins. Zhu et al. (2005) also reported a positive relationship between environmental management and economic performance in Chinese manufacturing companies. Chien and Shih (2007) found significant evidence between corporate GSCM practices and environmental and financial performance of the electrical and electronic industries in Taiwan. Thus, it is expected that:

$\mathrm{H}_{\mathrm{r}}$ : Green Supply Chain Management has a positive and significant effect on the organizational development. 


\subsection{GREEN SUPPLY CHAIN MANAGEMENT (GSCM) AND GREEN MARKETING (GM)}

The recognition of supply chain management as a strategic function for competitive advantage has led authors like Mentzer, Stank and Esper (2008) to talk about the importance of the connection between supply chain management and marketing. Supply chain management focuses on information sharing and collaboration, while marketing is dedicated to value addition, transforming a commodity into a differentiated product, valued making use of elements such as brand, services provided to customers, packaging or other add-ons.

Shang, Lu and Li (20I0) developed a taxonomy for GSCM capabilities in the electronics industry of Taiwan. As a result, they formed four clusters: I. poorly GSCM oriented cluster; 2 . green marketing oriented cluster; 3 . green supplier oriented cluster; and 4. green inventory oriented cluster. From the examination of performance differences among clusters of companies and dimensions of capabilities in GSCM, it was found that the green marketing group was better oriented to performance marketing (branding, sales, increase in market share, customer satisfaction and loyalty) and economic performance (profitability).

Similarly, Dahlstrom (20II) divided green marketing into four sets of practices: market analysis (segmentation and positioning); integrated communication (communication, message strategies, green brands and certifications); supply strategies; and pricing strategy (costs evaluation, demand, legal barriers, competition, and corporate mission coherence).

Concerning the integration between SCM and green marketing, according to Rao and Holt (2005), when implementing the green supply chain management, companies expected not only an improvement in environmental performance, but also corporate image recognition, competitive advantage and marketing exposure. Thus, firms that implement green supply chain management should expect:

$\mathrm{H}_{2}$ : Green Supply Chain Management has a positive and significant effect on Green Marketing.

\section{GREEN MARKETING (GM) AND ORGANIZATIONAL PERFORMANCE (OP)}

Given the increasing environment degradation, consumers have pressured companies to manufacture environmentally sustainable products. Therefore, companies have adopted terms such as green marketing and green marketing as a means to develop closer relationships with their customers. 
However, green marketing studies are recent. Peattie (200I) divided the green marketing history in three phases: the ecological phase (from I960 to I985), which had no useful practical results, except for government awareness as a form of response to environmental activism; the environmental phase (from I985 to 2000), which presented limited practical results due to the difficulty in proving products' green attributes and companies faced consumers' distrust, but left a legacy of efficiently implementing experiences such as packaging recycling; and the sustainable phase (from 2000 on), when companies incorporated product consumption requirements that have low impact on the environment, and the green supplies became relevant to corporations.

Studies devoted to the importance of green marketing can be observed in Biloslavo and Trnavcelic (2009); green marketing segmentation in Banyte, Brazioniene and Gadeikiene (20I0); green marketing performance impacts in Shang et al. (20IO), Fraj et al. (2OII), Ham and Lee (2OII) and Zhang (2OIO), who focused specifically on the implementation of green or environmentally sustainable residential building. Please note that green marketing activities without grounding in a real differential characterize "greenwashing" (Peattie, 200I; Furlow, 2010).

Ham and Lee (20II) looked into the connections between green marketing practices and financial performance in the food industry through electronic sites of American restaurants. The results showed negligible effects on the performance of organizations with green practices in their websites. Mathur and Mathur (2000) evaluated the impact of green marketing corporate advertisements on the economic performance, measured by the value of shares. It became clear that the market value of the average company declined over a period of ten days before and ten days after the advertisement. Besides, ads related to green products, recycling efforts and appointments of environmental managers influence the actions to a negligible extent, while the ad green promotional efforts produced significant negative effects on stock prices.

On the other hand, Fraj et al. (2OII) indicated that organizations, which adopted green marketing strategies, improved the profitability by optimizing marketing performance and cost reduction. The study also revealed that the environmentally oriented companies were more likely to achieve both a higher operational performance and environmental marketing practices. Baker and Sinkula (2005) also obtained a positive relationship between environmental marketing and the success of new products, which increased in turn the market share. Thus, it is expected that:

$\mathrm{H}_{3}$ : Green Marketing has a significant positive effect on Organizational Performance. 


\section{GREEN MARKETING MEDIATION BETWEEN GREEN SUPPLY CHAIN MANAGEMENT AND ORGANIZATIONAL PERFORMANCE}

Several studies have been conducted in different markets and countries to verify the direct effect of GSCM and organizational performance such as Wagner, Schaltegger and Wehrmeyer (200I) and Bowen et al. (200I).

Other studies, such as Green Jr, Whitten and Inman (20I2), established that supply chain management had an indirect effect on the performance of American companies in different fields and concluded that marketing performance was the path that led to financial results. Idar and Mahmood (20II), based on 356 small and medium-sized companies in Malaysia, also found that marketing had a mediating role in the relationship between entrepreneurial orientation and performance. Despite the examples of mediation, in which the antecedent variable was not about green supply chain management, results showed the importance of marketing as a mediating variable between the antecedent variable in supply chain management and performance.

Thus, it is expected that:

$\mathrm{H}_{4}$ : Green marketing mediates the relationship between green supply chain management and organizational performance.

\section{METHODS}

\section{NATURE, TYPE, SUBJECT OF THE RESEARCH, SAMPLING AND DATA COLLECTION INSTRUMENTS}

To operationalize the theoretical model illustrated in Figure I, an exploratory and descriptive study was conducted. A previous literature review of I27 articles on GSCM and I4O articles on green marketing was conducted on Ebsco and ProQuest bases. A list of assertions was obtained, whose measurements and scales had the potential for operationalization of GSCM, green marketing and organizational performance constructs. Measurements and scales of constructs, based on authors like Srivastava (2007), Zhu, Geng, Fujita and Hashimoto (2OIO) and Dahlstrom (2OII), were submitted to an exploratory study to better understand the adequacy of the theoretical model structure with companies and the industry in which they operate and, particularly, to examine environmental factors that could affect the definition of the research problem as legal, economic and technological skills of companies. The collection of data for the exploratory study took place in August 20II, making use of in-depth interviews, recorded 
on audio, together with a convenience sample of ten managers who work in the construction business (Malhotra, 200I). The result of this study was used to develop the data collection tool adapted to the reality of Brazilian construction industry scenario.

Before its completion, the data collection tool was evaluated by three experts in the construction market to point out any errors in comprehension and scale codes (Brace, 2004). The collection tool was completed trough the definition of a structured questionnaire consisting of 47 assertions and five blocks. The first block, concerning GSCM with 26 assertions, subdivided into green corporate practices $(\mathrm{CP})$, with eight assertions, green design (GD) with nine assertions, and green construction (GC), with nine assertions. The second block on Green Marketing (GM) with nine assertions, and the third block on the organizational performance $(\mathrm{OP})$, I2 assertions. In these three blocks, respondents were requested to mark an ' $x$ ' in each statement, the degree of agreement on a scale of disagreement and agreement ranging from $\mathrm{I}$ to 5 , where $\mathrm{I}=$ Strongly Disagree and $5=$ Strongly Agree. Two other blocks referred to the characteristics of respondents and businesses.

Once questionnaire was defined, the choice of companies by judgment was proceed with (Malhotra, 200I), to be part of the sample to collect data from a base of I6,380 e-mail addresses of companies related to construction and development in Brazil. The questionnaire was available on the website for the collection of data online, inviting the participants by letter and e-mail accompanied by a presentation of the objectives of the research and targeted at managers (directors, managers and engineers).

\subsection{DATA TREATMENT, METHOD LIMITATIONS AND STUDY BOUNDARIES}

The following methods were used to treat collected data:

I. Descriptive statistics, to learn about the characteristics of respondents, companies and assertions. With the examination of the data, some questionnaires were excluded due to atypical information and/or incomplete filling, which could result in errors in data entry or omission of answers by the respondents. In addition, we sought to understand how the distribution of the data collected in the univariate approach (average, standard deviation, and format) and bivariate (correlation).

2. Exploratory and confirmatory factor analysis techniques to debug and define the underlying structure of the data collected. Hair Jr., Anderson, Tatham and Black (2005) recommend that the factor loadings exceed 0.7 for the factor to explain at least $50 \%$ of the variance. After clearing the measurement model, 
we analyzed the one-dimensionality and validity of composite reliability, convergent and discriminant of measurements of the constructs of the model. The one-dimensionality was evaluated by internal consistency of the factor loadings of each construct, given by $\alpha$-Cronbach, where the value of 0.7 is the lower limit of acceptability. As the measurement of internal consistency assumes one-dimensional, but does not guarantee its existence, the composite reliability was also evaluated, which represents a more robust measurement construct. Both the one-dimensionality and the composite reliability measurements have an acceptable reference value of 0.7 , and may be below 0.7 if the research is exploratory in nature.

Convergent validity was assessed by high factor loadings and the average variance extracted (AVE). Both the factor loadings and the average variance extracted (AVE) have the higher reference value of 0.50 (Hair Jr. et al., 2005). In assessing the discriminant validity, we used the criterion of Fornell and Larker (I98I), in which it is considered appropriate when the square root of the average variance extracted (AVE) exceeds the shared correlation of the construct with the rest of the measurement model.

3. Structural equation modeling, the method of paths (path analysis) to examine the strengths and statistical significance between the constructs of the model. In structural equation modeling, the PLS-PM (Partial Least Squares-Path Modeling) was adopted, which displays the following characteristics: I. PLS-PM estimation is based on partial least squares; 2. allows the use of small samples (Smith \& Langfield-Smith, 2004); 3. admits the absence of probability distribution properties such as, for example, normal, and admits using interval scales (Jöreskog \& Wold, I982); 4. can include indicators of reflective and formative measurements simultaneously (Henseler, Ringle, \& Sinkovics, 2009). In this case, the presence of indicators of formative measurements presents multicollinearity problems (Diamantopoulos \& Winklhofer, 200I). To detect the presence of multicollinearity, we adopted the limit for tolerance equal to o.Io as recommended by Hair Jr. et al. (2005), which corresponds to a value of Variance Inflation Factor (VIF) greater than Io; 5. it is recommended for prediction instead of explanation (Henseler et al., 2009, Jöreskog \& Wold, I982); 6 . the relative strengths of variables can be inferred by the factor loadings (Fornell \& Laker, I98I); 7. it allows the use of bootstrapping to assess the statistical significance of the coefficients; 8. adjustment of the measurement model can be obtained by GoF indexes (Goodness-of-Fit) defined as the geometric average of the average variance extracted and the coefficient of determination $\left(\mathrm{R}^{2}\right)\left(\mathrm{GoF}=\sqrt[2]{\overline{A V E} x \overline{\mathrm{R}^{2}}}\right)$ and the coefficient of determination $\mathrm{R}^{2}$ as suggested by Tenenhaus, Vinzi, Chatelin and Lauro (2005) and Hair Jr. et al. (2005), respectively. Cohen (1977) and Wetzels, Odekerken-Schröder 
and Van Oppen (2009) suggest the threshold values of 0.26 and 0.36 for GoF and $\mathrm{R}^{2}$, respectively.

4. Iacobucci et al. (2007) approach to test statistically the mediation of GM in the relationship between OP and GSCM. The mediation is detected with the help of weakening the direct relationship between GSCM and OP (path c, Figure I) where the GM is present. It means that the mediation will have been found if GSCM does not have any effect on OP when GM is controlled. Iacobucci et al. (2007) demonstrated the superiority of the structural equation modeling in relation to multiple linear regression by Baron and Kenny (I986) to test the effect of the mediating variable in the relationship between independent and dependent variables statistically. The reason, according to Iacobucci et al. (2007), is that the models have become more complex with construct scenarios of multiple indicators and additional antecedents and consequents. In this sense, the approach of mediation from the perspective of structural equation modeling of Iacobucci et al. (2007) is more robust than Baron and Kenny's approach (I986) developed from the point of view of linear regression.

5. Sobel z test (Sobel, I982). As a control to verify that the magnitude of difference in the relationship between GSCM (independent variable) and OP (dependent variable), given by paths c and c', shown in figures 2 and 3, was statistically significant with or without the mediation of GM (moderator variable).

FIGURE 2

PATTERN WITH GM MEDIATION

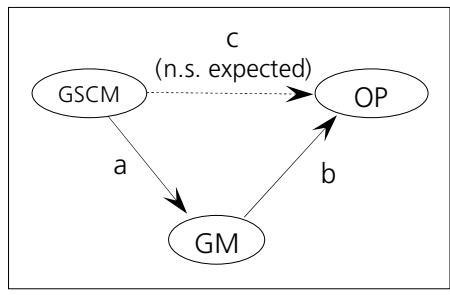

Note: n.s: non-significant

Source: Elaborated by the authors.

\section{FIGURE 3}

PATTERN WITHOUT GM MEDIATION

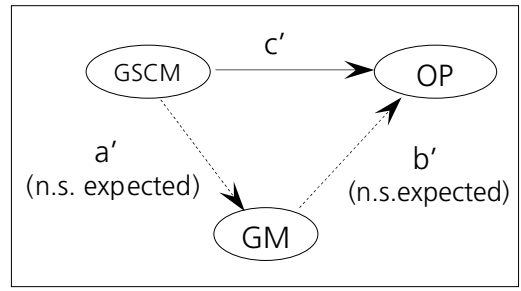

Note: n.s: non-significant

Source: Elaborated by the authors.

Sobel $\mathrm{z}$ test formula is: $\mathrm{z}=\frac{c-c^{\prime}}{\text { Standard Error }}=\frac{a \times b}{\sqrt{b_{2} S_{a}^{2}+a^{2} S_{b}^{2}}}$

Given that:

a, b, c and c' are structural coefficients obtained from the three variables.

$\mathrm{S}_{\mathrm{a}}$ e $\mathrm{S}_{\mathrm{b}}$ are the standard errors related to the coefficients a and $\mathrm{b}$. 
MacKinnon (2008) suggests that the difference between $c-c$ ', shown in figures 2 and 3 , is given by the product [a $\mathrm{x} b]$. The logic behind the magnitude of the mediation coefficients, given by the product [a $\mathrm{x} b]$, is that if $\mathrm{X}$ affects $\mathrm{Y}$ indirectly through $\mathrm{M}$, the mediating effect is also known as the indirect effect. The effect of $\mathrm{X}$ on $\mathrm{Y}$ after the adjustment for $\mathrm{M}, \mathrm{c}^{\prime}$, is known as the direct effect. The mediating effect is also equal to the difference between the coefficients $c$ and $c^{\prime}$ [ $\left.c-c^{\prime}\right]$. As a result, the total effect can be subdivided into a direct effect, $c^{\prime}$, and an indirect effect, $[\mathrm{a} \times \mathrm{b}]=\mathrm{c}-\mathrm{c}^{\prime}$.

Depending on the statistical significance determined by tests, we continued the classification of the mediation by type, presented by Iacobucci et al. (2007), determining whether it is complete, partial or there is no mediation.

The main limitations of the method of the study were: $\mathrm{I}$. the use of a non-random sample of Brazilian companies, which gives rise to possible biases in the responses of research subjects; 2 . the size of the sample. Although we used the technique of PLS-PM, which does not require the normality of the data, the condition of five respondents per variable has not been reached (Hair Jr et al., 2005), leading to a cautious interpretation of the findings, and; 3. the multidisciplinary aspect of the study involving subjects such as marketing, operations, logistics, supply chain and the environment, which makes the analysis more complex.

In addition, the study had the following boundaries: I. concerning the scope, the study was conducted in the Brazilian civil construction sector, consisting of heterogeneity of companies of all sizes, organizational structures, and technologies. However, due to their importance in relation to GDP $(9.2 \%$ in 20IO) and the amount of people employed (Io million people employed part or full time), it represents an important economic sector in the country and one of the sectors that will grow until 2022, with growth projections of $6.1 \%$ per year (Construbusiness, 20IO); 2. concerning the theme: the GSCM, marketing and performance constructs were examined in the construction sector. Unlike the manufacturing chain, supply chain studies in construction are recent, pointing to the best way to solve problems in construction sites (Vrijhoef, Koskela, \& Howell, 200I) and; 3. concerning the conception, the research was conducted through the cross-section, i.e., a reading held in a single period.

\section{ANALYSIS OF DATA AND RESULTS}

In the period running from April to August 20I3, I,435 questionnaires were selected and sent to companies, addressed to managers (directors, managers and 
engineers). Out of those, I33 were returned (or 9.3\% of the total), of which 30 of them by regular mail and I03 by electronic mail. Io9 were fully completed and 24 had some unfilled fields. Partially completed questionnaires had the missing information complemented via telephone contact.

\subsection{DEMOGRAPHIC PROFILE OF SAMPLE}

I. Regarding the companies, $62.4 \%$ are located in the State of São Paulo and $37.6 \%$ in I5 other states. $47.5 \%$ of companies are in the Metropolitan Area of São Paulo and 67.3\% in Southeast Brazil. Although the sample concentrated in the Southeast (with a relatively higher GDP in 20I0), it was described as nationwide. Regarding the sector, $75.4 \%$ of companies were in land developing and/or construction areas, demonstrating that the sample focused on the last two supply chain links. About size, I6.7\% were made up of micro (up to I9 employees), small (20 to 99 employees) and medium companies (between roo and 499 employees), each of these classifications represented $35.3 \%$ of the sample, and $12.7 \%$ were large companies (over 500 employees). The classification of companies regarding size was done according to the Instituto Brasileiro de Geografia e Estatística - IBGE (2015) criteria. However, it was not computed if employees were themselves, outsourced or temporary contracts. The respondent was asked to report only the number of people employed by the company at the time of the survey.

2. A share of $68.8 \%$ of respondents had worked for more than five years in their respective companies and in the sector, indicating that they know both the market and the company. As for their activities, $45.7 \%$ of respondents were involved in the execution of works and 31.5\% in the project. The remaining II.7\%, 5.5\% and 6.3\% worked in finance, marketing and product, respectively. As for the training, $54 \%$ of respondents attended Engineering, $22 \%$ - Management, $15 \%$ - Architecture and 9\% - other courses.

In summary, the scope of the sample according to geographic region, segment, size and profile of the respondents suggested that the data collected provide minimum conditions of reliability and quality for research.

\section{VALIDATION OF MEASUREMENTS AND SCALES OF CONSTRUCTS}

To validate the measurements and scales of data collected from I33 respondents, we used the factor analysis of SmartPLS 2.0 software. After several 
runs and interactions, it obtained an underlying structure made up of 38 assertions with factor loadings above $0.7 \mathrm{I}$, when the recommended value is 0.7 , distributed into five constructs called: Corporate Practices (CP) with 8 assertions, Green Project Enterprises (GP) with 5 assertions, Green Construction (GC) with 6 assertions, Green Marketing (GM) with 8 assertions and Organizational Performance (OP) with II assertions. Therefore, from 47 assertions, 38 or $80.9 \%$ of the total remained. The cut in the assertions (19.1\% of total) can be justified by the lack of clarity or understanding of assertions (or biases on the part of respondents) or size of the sample. Among the discarded assertions, some were related to power generation within the works and supplier development from an environmental point of view. Suggestions to minimize the discard of assertions are discussed below in the concluding remarks of this article.

Averages, standard deviations and factor loadings of each of the assertions, refined in their respective constructs, are given in Appendix A.

The structure of the constructs obtained by the factorial analysis has been validated as: I. the one-dimensionality, provided by the $\alpha$-Cronbach coefficient and the composite reliability, both measurements showed values above the recommended minimum $0.70 ; 2$. the convergent validity, measured by factor loading and average variance extracted (AVE) also achieved values above the recommended minimum of 0.7 and 0.5 , respectively, and; 3. the discriminant validity given by shared variances and obtained by the square root of average variance extracted from each construct were higher than the correlations between the constructs, as shown in Table I (diagonal matrix in italics).

As for multicollinearity due to the inclusion of formative constructs in the model, Tolerance values were between 0.494 and I.000 (VIF between I,००० and 2,026), within the recommended limits (minimum of o.I for Tolerance and VIF above Io).

Descriptive statistics data, such as the format used in data distribution (asymmetry and flattening), average and standard deviation of the constructs, bivariate correlation, number of original assertions and number of assertions after the refinement, $\alpha$-Cronbach measurements, Average Variance Extracted (AVE) and Composite Reliability (CR) are presented in Table I. 
TABLE I

DESCRIPTIVE STATISTICS,

CORRELATION, $\alpha$-CRONBACH, AVE E CR

\begin{tabular}{|c|c|c|c|c|c|c|c|c|c|c|}
\hline CONSTRUCTS & $S K^{A}$ & $K U^{B}$ & AVERAGE & $\begin{array}{l}\text { STANDARD } \\
\text { DEVIATION }\end{array}$ & 'GSCM & GM & $\mathrm{OP}$ & CP & GP & $\mathrm{GC}$ \\
\hline 'GSCM (Chain Management) & -0.46 & -0.61 & 3.50 & 0.99 & 0.729 & & & & & \\
\hline GM (Green Marketing) & 0.12 & -1.18 & 2.81 & 1.21 & $0.753^{* *}$ & 0.904 & & & & \\
\hline OP (Performance) & -0.53 & -0.11 & 3.39 & 1.05 & $0.551^{* *}$ & $0.573^{* *}$ & 0.922 & & & \\
\hline CP (Corporate Practices) & -0.31 & -0.94 & 3.26 & 1.14 & $0.705^{* *}$ & $0.508^{* *}$ & $0.219^{* *}$ & 0.812 & & \\
\hline GP (Green Project) & -0.68 & -0.48 & 3.71 & 1.07 & $0.913^{* *}$ & $0.683^{* *}$ & $0.576^{* *}$ & $0.439^{* *}$ & 0.892 & \\
\hline GC (Green Construction) & -0.51 & -0.56 & 3.65 & 1.06 & $0.930^{* *}$ & $0.719^{* *}$ & $0.575^{* *}$ & $0.454^{* *}$ & $0.866^{* *}$ & 0.899 \\
\hline \multicolumn{5}{|c|}{ Amount of new measures $\rightarrow$} & 47 & 9 & 12 & 8 & 9 & 9 \\
\hline \multicolumn{5}{|c|}{ Amount of measures after depuration $\rightarrow$} & 38 & 8 & 11 & 8 & 5 & 6 \\
\hline \multicolumn{5}{|c|}{ Unidimensionality ( $\alpha$-Cronbach) $\rightarrow$} & 0.949 & 0.968 & 0.983 & 0.926 & 0.936 & 0.953 \\
\hline \multicolumn{5}{|c|}{ Average Variance Extracted (AVE) $\rightarrow$} & 0.532 & 0.818 & 0.851 & 0.660 & 0.796 & 0.809 \\
\hline \multicolumn{5}{|c|}{ Composite reliability (CR) $\rightarrow$} & 0.954 & 0.973 & 0.984 & 0.939 & 0.951 & 0.962 \\
\hline
\end{tabular}

Note: ${ }^{\mathrm{I}}$ Second order construct; ${ }^{\mathrm{a}}$ Sk Value (Skweness) out of range -I a +I indicates a substantially asymmetrical distribution; ${ }^{\mathrm{b}}$ positive Ku Value (Kurtosys) indicates a relatively high distribution and a negative value indicates a relatively flat distribution; ${ }^{* * *}$ indicates that the assertion coefficient is significant at $\mathrm{I} \%$. Diagonal values in italics represent the square root of Average Variance Extracted (AVE). Average Variance Extracted (AVE) is the same as commonality.

Source: Elaborated by the authors.

After validating the structures of the constructs and their measurements and scales, we proceeded to the evaluation of the relationship between the constructs of the measurement model. OF THE MEASUREMENT MODEL

Figure 4 illustrates the results obtained with the SmartPLS 2.0 application, the PLS-PM technique. 


\section{FIGURE 4}

\section{MEASUREMENT MODEL:}

(A) WITH MEDIATION AND (B) WITHOUT MEDIATION

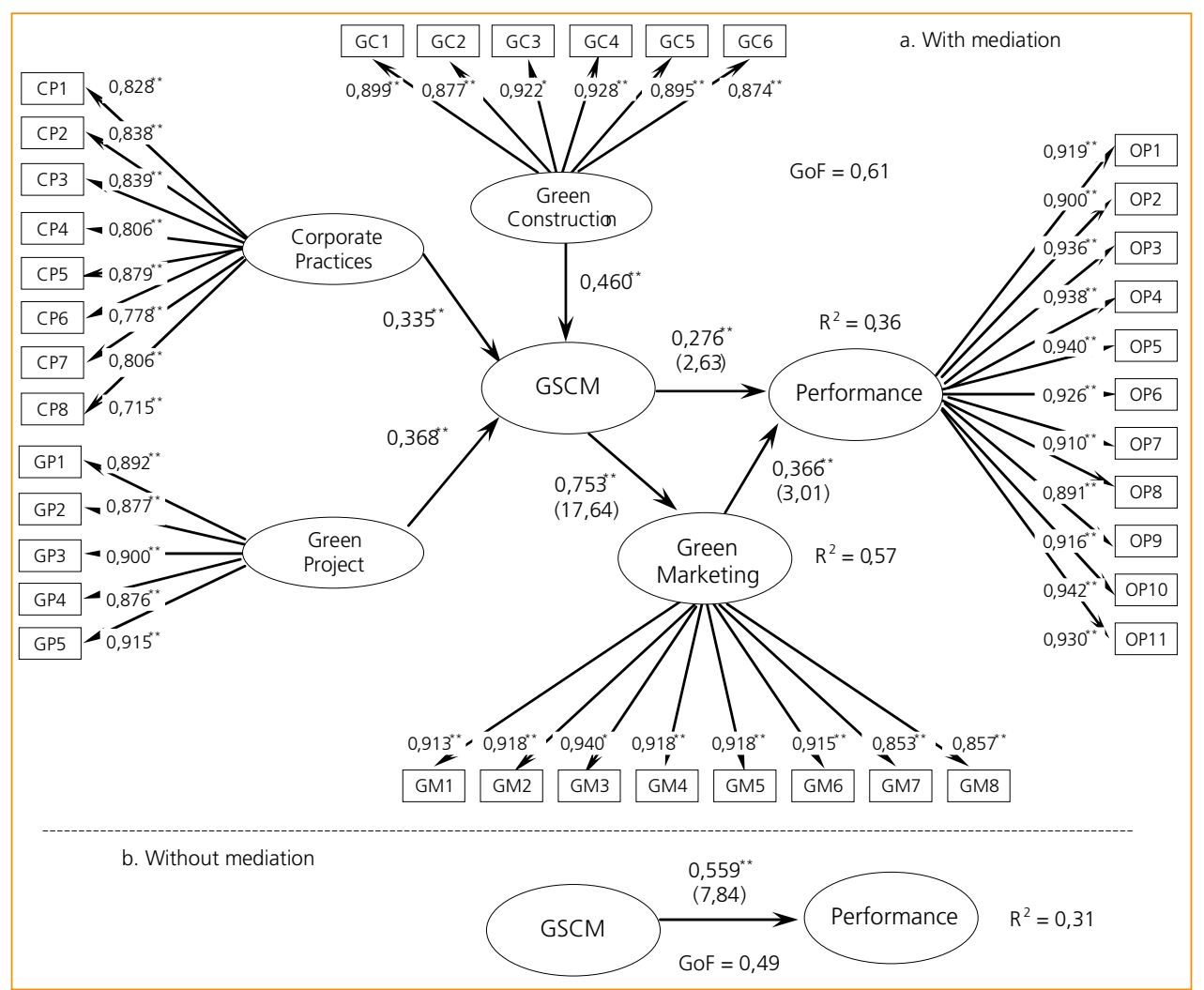

Note: $* *$ statistically significant structural coefficient $[\alpha \leq 0,0$ I].

Source: Elaborated by the authors.

In Figure 4, the statistical significance of corporate practices (CP), green project (GP) and green construction (GC) constructs can be observed, indicating their importance in the management of green supply chain (GSCM) as presented in arguments by authors such as Srivastava (2007) and Bowen et al. (200I).

Regarding the overall fit provided by GoF index (Goodness-of-fit) to the models shown in Figures 4(a) and 4(b), they were 0.6I and 0.49 for the models with and without mediation respectively, values above the recommended 0.26 . As for the adjustment given by the R2 determination coefficient for the relationship [GSCM $\rightarrow$ OP] and [GSCM $\rightarrow$ GM] of the model in Figure 4(a) with mediation, they were 0.36 and 0.57 , respectively. For the relationship [GSCM $\rightarrow$ OP] 
of the model in Figure 4(b), without mediation, it was 0.3 I. Although in the model in Figure $4(\mathrm{~b})$, without mediation, the value of $\mathrm{R}^{2}$ determination coefficient was 0.3I (close to the recommended 0.36). In general, it can be considered that there was evidence that the collected data were a good fit for the measurement model developed.

As for the measurement model with mediation, shown in Figure 4(a), the GSCM had a direct effect on organizational performance with a structural coefficient of 0.276 and t-statistic equal to 2.63, and supported the hypothesis $\mathrm{H}_{\mathrm{r}}$. The GSCM affected the GM with a structural coefficient equal to 0.753 and t-statistic equal to 17.64 and supported the hypothesis $\mathrm{H}_{2}$, which in turn influenced the performance with a structural coefficient equal to 0.366 and t-statistic equal to 3.0I and supported hypothesis $\mathrm{H}_{3}$.

As for the measurement model without mediation in Figure 4(b), it demonstrated that GSCM had a direct effect on operational performance with a structural coefficient of 0.559 and t-statistic equal to 7.84 , much higher than Figure 4 (a) with a coefficient of 0.276 and t-statistic equal to 2.63 . This meant that green marketing as a mediator helped predict organizational performance.

Table 2 presents the structural coefficients, standard error, and the values of $\mathrm{t}$-statistics of the relations in estimation model.

\section{TABLE 2}

STRUCTURAL COEFFICIENTS, STANDARD ERROR (S) AND STATISTICS (T)

\begin{tabular}{|c|c|c|c|c|c|}
\hline STRUCTURAL EQUATIONS & $\begin{array}{l}\text { STRUCTURAL } \\
\text { COEFFICIENTS }\end{array}$ & $\begin{array}{c}\text { STANDARD } \\
\text { ERROR } \\
S\end{array}$ & $\begin{array}{c}\text { STATISTICS } \\
T\end{array}$ & HYPOTHESIS & $\begin{array}{l}\text { DECISION } \\
(\alpha \leq 0,05)\end{array}$ \\
\hline \multicolumn{6}{|l|}{ With Mediation } \\
\hline Supply management $\rightarrow$ Performance (c) & 0,276 & 0,105 & $2,63^{* *}$ & $\mathrm{H}_{3}$ & supports \\
\hline Supply management $\rightarrow$ Green Marketing (a) & 0,753 & 0,043 & $17,64^{* *}$ & $\mathrm{H}_{1}$ & supports \\
\hline Green Marketing $\rightarrow$ Performance (b) & 0,366 & 0,121 & $3,01^{* *}$ & $\mathrm{H}_{2}$ & supports \\
\hline \multicolumn{6}{|l|}{ Without Mediation } \\
\hline Supply management $\rightarrow$ Performance $\left(c^{\prime}\right)$ & 0,559 & 0,071 & $7,84^{* *}$ & & \\
\hline
\end{tabular}

Source: Elaborated by the authors.

After the assumptions of mediation, argued by Iacobucci et al. (2007), were verified, we proceeded to verify whether the difference of structural coefficients 
of the direct (path c) and indirect (path c') relationship, shown in figures 2 and 3 were statistically significant.

Applying the Sobel $\mathrm{z}$ test (I982), where $\mathrm{a}=0.753 ; \mathrm{b}=0.366 ; \mathrm{S}_{\mathrm{a}}=0.043$; $\mathrm{S}_{\mathrm{b}}=$ O.I2I, we have:

Sobel $\mathrm{z}$ test $=\frac{0,753 \times 0,366}{\sqrt{0,366^{2} \times 0,043^{2}+0,753^{2} \times 0,121^{2}}}=2.98 \rightarrow$ value- $\mathrm{p}=0.003$

Therefore, the difference of the structural coefficients of the paths between GSCM and organizational performance, directly and indirectly, was statistically significant $(\alpha \leq 0, \mathrm{OI})$, confirming, in fact, the mediating role of GM in the relationship between GSCM and organizational performance.

In this case, according to the typology of Iacobucci et al. (2007), the mediation of green marketing was considered partial, with a direct effect on the performance of GSCM equal to 0.276 . The indirect effect was equal to $0.276[0.753 *$ $0.366=0.276]$. The total effect was equal to $0.552[0.276+0.753 * 0.366=0.552]$. The proportion of mediation in the variance of organizational performance (OP) explained directly and indirectly by the management of green supply chain (GSCM) was $50.0 \%([0.753 * 0.366] /[(0.753 * 0.366)+0.276]=0.5)$.

Therefore, the $\mathrm{H}_{4}$ hypothesis was supported partially. The approaches of Baron and Kenny (1986), as well as of Iacobucci et al. (2007), state that for the mediation to be complete, paths a and b should be significant and path $\mathrm{c}$ non-significant, which did not occur.

\section{CONCLUSION AND SUGGESTIONS FOR FUTURE RESEARCH}

Results revealed that green marketing partially mediates the relationship between the management of the supply chain and green organizational performance. The implications of theoretical and practical nature of the results obtained are discussed below.

Practical implications: Regarding GSCM practices and green marketing in construction, the two main measurements of each construct, the influences on organizational performance subject to the weighted average assertions shown in Appendix A of the strongest influence to the weakest were: corporate practices that encouraged employee involvement in environmental issues, corporate practices in mission and vision statements, designs that use energy-saving devices, development projects with meters to save water, the reuse of rainwater or sewage, construction works with reduction of waste materials, construction works with the reuse of materials in the construction site, ads for green products, green marketing actions to improve the corporate image. In aggregate, on a scale 
of I to 5, as shown in Table I, green marketing obtained a weighted average of 2.8I and GSCM obtained 3.50.

Among the many positive influences observed, an important one is the need to use new technologies in the GSCM practices, which resulted in considerable costs. Nevertheless, there is the recognition that many companies prefer out-of-the-box or less disturbing solutions, suggesting more investment in end-of-pipe technologies, which keep production processes or products with low changes (Vachon \& Klassen, 2006).

In general, green investments in construction, in spite of market imperfections, favor the internalization of compatible costs to preserve the environment. The acceptance of certifications such as LEED (Leadership in Energy and Environmental Design) or ecolabels may minimize market failures. In this sense, green marketing helps to correct market imperfections or asymmetry of information through the collection and provision of information to consumers (Giordano, 2000).

Theoretical implications: The study, conducted in the Brazilian civil construction economic segment, adds to other existing studies which demonstrated in different fields of activities, regions or countries: $\mathrm{I}$. the relationship between GSCM and performance, such as Alvarez Gil et al. (200I), and Chien and Shih (2007), Kim et al. (20II), Rao and Holt (2005), Shang et al. (20I0) and Zhu et al. (2005); 2. the relationship between green marketing and performance investigated by Baker and Sinkula (2005), Fraj et al. (20II) Ham and Lee (20II) and Dahstrom (2OII); 3. the importance of green marketing as a mediating factor between SCM and performance, approached by Idar and Mahmood (2OII) and Green Jr. et al. (2012).

As noted, there are several estimation models for the constructs of this study: GSCM, organizational development and green marketing. In essence, what we sought in theory was to understand the importance of the mediation of green marketing in the relationship between GSCM and organizational performance. To this end, we used models previously developed that, combined, could be reproduced or distorted (Popper, I977), to obtain convergent measurement models. Towards the convergence of supply chains and environmental sustainability (ecological or green), Linton, Klassen and Jayaraman (2007) argued that the operations are moved from local optimization of environmental factors to the entire supply chain for the production, consumption, customer service and elimination of waste products. However, because of the diversity of measurements and scales and the geographic location of companies, obtaining a converged model still requires a lot of research and time, especially due to the need for comparison or building alternative models.

Therefore, the result obtained, practices, theoretical implications and the evidence of a relationship between GSCM and organizational performance, 
direct and indirect (partially moderated by green marketing), show that the green marketing in construction companies still has room to improve communication and image, to foster both the supply and the consumption of green products.

Construction incorporates a huge dispersion of competitive conditions such as size, control of the property of company capital, technological upgrading and asymmetry in financial leverage capabilities that generate different competition standards. Thus, this study helped minimize these differences, through an understanding of the impact of marketing due to the assumption of a new approach to corporate responsibility for the environment in the supply chain management, as well as, expanding the literature and GSCM practices integrated with green marketing and environmental management.

Finally, the following is suggested to improve the study:

I. Increase the size of the sample to improve the power of generalization and possibly classify the adoption in different locations (region or country) and type of construction (commercial or residential building). The obtaining of more respondents can be accomplished by replicating the electronic data collection tool, making use of qualified databases with promoters working at events in the construction area, forums, trade and professional associations;

2. Develop a research with a longitudinal concept. By conducting research at certain intervals of time, it is possible to analyze changing processes in a broader, social, economic and political context surrounding the company. Thus, explanations should arise from the examination of changing processes patterns (Easterby-Smith, Thorpe, \& Lowe, I999); and

3. Carry out research on innovative and emerging topics such as "enviropreneurial" marketing strategy, as a combination of ecological concerns with marketing strategy, greening the supply chain, where the buyer uses their purchasing power to demand a better environmental performance of the supplier (upstream supply chain).

\section{MARKETING VERDE COMO MEDIADOR ENTRE GESTÃO DA CADEIA DE SUPRIMENTOS$$
\text { E DESEMPENHO }
$$

\section{RESUMO}

Objetivo: O estudo visa a explorar e descrever a mediação do marketing verde na relação entre a gestão da cadeia de suprimentos e o desempenho das empresas. 
Originalidade/lacuna/relevância/implicações: Pretendeu-se preencher uma lacuna de natureza epistemológica sobre o marketing verde, constatando-se que este, por estar presente na regressão, diminui a magnitude do relacionamento entre gestão da cadeia de suprimentos e desempenho nas empresas da construção civil brasileira. Principais aspectos metodológicos: Utilizou-se o método quantitativo de natureza exploratória e descritiva. Do estudo exploratório participaram dez gestores. No descritivo, precedido de pré-testes junto a três especialistas, contou-se com uma amostra de 133 respondentes. Os dados foram tratados por técnicas de estatística descritiva, análise fatorial, regressão linear múltipla e modelagem em equações estruturais.

Síntese dos principais resultados: Os dados evidenciaram que o marketing verde medeia, parcialmente, a relação entre gestão da cadeia de suprimentos e o desempenho das empresas.

Principais considerações/conclusões: Como implicações teóricas, o estudo reforça correlações positivas entre os constructos utilizados no setor pesquisado. Recorreu-se a modelos previamente desenvolvidos que, combinados, poderiam ser reproduzidos ou falseados, para no final se obter modelos de mensuração convergentes. Como aplicação prática, identificou-se o envolvimento de funcionários em temas ambientais, missões e visões com declarações explícitas sobre economizar energia e água e ações de marketing verde para melhoria da imagem corporativa, como a obtenção de certificações ambientais. Como conclusão, verifica-se que as empresas da construção civil têm espaço para melhorar a comunicação e a imagem para estimular tanto os suprimentos como o consumo de produtos verdes.

\section{PALAVRAS-CHAVE}

Marketing verde. Desempenho organizacional. Gestão de cadeia de suprimento. Cadeia de suprimento verde. Cadeia de suprimento na construção civil.

\section{MARKETING VERDE COMO UN MEDIADOR ENTRE LA GESTIÓN DE CADENA DE SUMINISTRO Y EL DESEMPEÑO}

\section{RESUMEN}

Objetivo: El estudio tiene como objetivo explorar y describir la mediación de marketing verde en la relación entre la gestión de la cadena de suministro y el rendimiento empresarial. 
Originalidad/laguna/relevancia/implicaciones: se tenía intención de llenar un vacío epistemológico sobre el marketing verde. La presencia de marketing verde en la regresión Disminuye la magnitud de la relación entre la administración y rendimiento de la cadena de suministro en empresas constructoras brasileñas. Principales aspectos metodológicos: Se utilizó el método cuantitativo de carácter exploratorio y descriptivo. El estudio exploratorio se llevó a cabo con io gerentes. El estudio descriptivo, precedido por pruebas previas con tres expertos, se hizo a través de una muestra de 133 participantes. Los datos se analizaron mediante técnicas de estadística descriptiva, regresión lineal múltiple y modelos de ecuaciones estructurales.

Síntesis de los principales resultados: Los datos indican que marketing verde media, en parte, la relación entre la gestión de la cadena de suministro y el rendimiento empresarial.

Principales consideraciones/conclusiones: Como implicaciones teóricas, el estudio refuerza correlaciones positivas entre las construcciones utilizadas en el sector observado. Recurrido a modelos desarrollados previamente que, en conjunto, podrían ser reproducidos o falsificado, el fin de obtener modelos de medición convergentes. Como aplicación práctica, se identificó la implicación de los trabajadores en temas ambientales, misiones y visiones con las declaraciones explícitas sobre la energía y el ahorro de agua y de las iniciativas de marketing verde para mejorar la imagen corporativa, tales como la obtención de certificaciones ambientales. En conclusión, parece que las empresas de construcción civil tienen espacio para mejorar la comunicación y la imagen de estimular tanto la oferta y el consumo de productos ecológicos.

\section{PALABRAS CLAVE}

Marketing verde. Desempeño organizacional. Gestión de la cadena de suministro. Cadena de suministro verde. Cadena de suministro en la construcción.

\section{REFERENCES}

Alvarez Gil, M. J., Jimenez, J. B., \& Lorente, J. C. (200I). An analysis of environmental management, organizational context and performance of Spanish hotels. Madrid: Omega, 29(6), 457-47I. Azambuja, M., \& O’Brien, W. J. (2009). Construction supply chain modeling: issues and perspectives. In W. J. O’Brien, C. T. Formoso, V. Ruben \& K. A. London. Construction supply chain management handbook. London: Taylor \& Francis Group.

Baker, W. E., \& Sinkula, J. M. (2005). Environmental marketing strategy and firm performance: effects on new product performance and market share. USA: Academy of Marketing Science Journal, fall, 33(4), 46I-475. 
Banyte, J., Brazioniene L., \& Gadeikiene A. (20I0). Investigation of green consumer profile: a case of Lithuanian market of eco-friendly food products. USA: Ekonomikair Vadyba - Economics and Management, 1(I5), 374-383.

Baron, R. M., \& Kenny, D. A. (I986). The moderator-mediator variable distinction in social psychological research: conceptual, strategic, and statistical considerations. Washington: Journal of Personality and Social Psychology, 51(6), Dec. I986, II73-II82.

Biloslavo, R., \& Trnavcevic, A. (2009). Web sites as tools of communication of a "green" company. USA: Management Decision, 47(7), I158-73.

Banco Nacional de Desenvolvimento Econômico e Social (BNDES). (20I5). BNDES e o Desenvolvimento Sustentável. Retrieved January II, 20I5, from http://www.bndes.gov.br/SiteBNDES/bndes/ bndes_pt/Areas_de_Atuacao/Meio_Ambiente/Rio2o/desenvolvimento_sustentavel.htm.

Bowen, F. E., Cousins, P. D., Lamming, R. C., \& Faruk, A. C. (200I). The role of supply management capabilities in green supply. USA: Production and Operations Management, 10(2), I74-I89.

Brace, I. (2004). Questionnaire Design: How to Plan, Structure and Write Survey Material for Effective Market Research, MRS. Market Research in Practice. UK: London \& Sterling, British Library Press. VA: London. United Kingdom.

Burgess, K., Singh, P. J., \& Koroglu, R. (2006). Supply chain management: a structured literature review and implications for future research. Bradford: International Journal of Operations \& Production Management, 26(7), 703-39.

Chakraborty, S. (2010). Concise Chronological road map of evolving green supply chain management concepts: a review. USA: IUP Journal of Supply Chain Management, III(4), 7-25.

Chien, M. K., \& Shih, L. H. (2007). An empirical study of the implantation of green supply chain management practices in the electrical and electronic industry and their relation to organizational performances. USA: International Journal of Environment Science and Technology, 4(3), 383-394.

Coelho, L. (20IO). Certificação ambiental. Revista Téchne, I55. Retrieved July 2, 20I2, from http:// www.revistatechne.com.br/engenharia-civil/155/artigor62886-i.asp.

Cohen, J. (I977). Statistical power analysis for the behavioral sciences (Revised Edition). New York: Academic Press.

Construbusiness. (20I0). Segundo Seminário da Indústria Brasileira de Construção. FIESP/CIESP. São Paulo.

Dahlstrom, R. (20II). Green marketing management. Masom, Ohio/USA: Southwestern.

Diamantopoulos, A., \& Winklhofer, H. M. (200I). Index construction with formative indicators: an alternative to scale development. USA: Journal of Marketing Research, 38(2), 269-277.

Easterby-Smith, M., Thorpe, R., \& Lowe, A. (I999). Pesquisa gerencial em Administração. São Paulo: Pioneira.

Furlow, N. E. (2010). Greenwashing in the new millennium. USA: The Journal of Applied Business and Economics, Marymount University, 10(6).

Fornell, C., \& Larker, D. F. (I98I). Evaluation structural equation models with unobservable variables and measurement error: algebra and statistics. USA: Journal of Marketing Research, 18(3), 382-388.

Fraj, E., Martínez, E., \& Matute, J. (2OII). Green marketing strategy and the firm's performance: the moderating role of environmental culture. USA: Journal of Strategic Marketing, 19(4), 339-355.

Giordano, S. R. (2000). Gestão ambiental no sistema agroindustrial. In M. F. Neves, Economia \& Gestão dos Negócios Agro-Alimentares. São Paulo: Pioneira, 255-280. 
Green Jr K. W., Whitten, D., \& Inman, R. A. (20I2). Aligning marketing strategies throughout the supply chain to enhance performance. USA: Industrial Marketing Management, 41(6), I008-10I8. Hair Jr, J. F., Anderson, R. E., Tatham, R. L., \& Black, W. C. (2005). Análise multivariada de dados (5nd ed.). Porto Alegre: Artmed.

Ham, S., \& Lee, S. (20II). US restaurant companies' green marketing via company websites: impact on financial performance. USA: Tourism Economics, October 20II, 17(5), I055-1069.

Henseler, J., Ringle, C. M., \& Sinkovics, R. R. (2009). The Use of Partial Least Squares Path Modeling in International Marketing. Advances in International Marketing, 20, 277-319.

Iacobucci, D., Saldanha, N., \& Deng, X. (2007). A meditation on mediation: evidence that structural equations models perform better than regressions: Pennsylvania: Journal of Consumer Psycho$\log$, 17(2), I40-154.

Idar, R., \& Mahmood, R. (20II). Entrepreneurial and market orientation relationships to performance: The SME perspective. Interdisciplinary Review of Economics and Management, 1(2), I-8.

Jöreskog, K. G., \& Wold, H. (I982). The ML and PLS Techniques for Modeling with Latent Variables: Historical and Comparative Aspects. In K. G. Jöreskog \& H. Wold (Eds.). Systems under indirect observation: causality, structure, prediction. Part I. Netherlands: North-Holland Publishing Company.

Kim, J., Youn, S., \& Roh, J. (2OII). Green supply chain management orientation and firm performance: evidence from South Korea. USA: International Journal of Services and Operations Management, 8(3), 283-304.

King, B., Felin, T., \& Whetten, D. (2009). Finding the organization in organizational theory: a meta-theory of the organization as a social actor. Organization Science, Articles in Advance, I-I6. Koskela, L. (1992). Application of the new production philosophy to construction. Stanford: Stanford University, Center of Integrated Facility Engineering. Technical Report 72, I-75.

Lambert, D. M. (I993). Strategic logistics management. Homewood: R. D. Irwin.

Linton, J. D., Klassen, R., \& Jayaraman, V. (2007). Sustainable supply chains: An introduction. USA: Journal of Operations Management, 25(6), I075-I082. DOI: I0.I0I6/j.jom.2007.0I.0I2.

MacKinnon, D. P. (2008). Introduction to statistical mediation analysis. New York: Taylor \& Francis Group.

Malhotra, N. K. (200I). Pesquisa em marketing: uma orientação aplicada. Porto Alegre: Bookman.

Mathur, L. K., \& Mathur, I. (2000). An analysis of the wealth effects of green marketing strategies. USA: Journal of Business Research, 50(2), 193-200.

Mentzer, J., Stank T., \& Esper T. (2008). Supply chain management and its relationship to Logistics, Marketing, Production and Operations Management. Journal of Business Logistics. 29(I), 3I-46. Murphy, R., Graber, M., \& Stewart, A. (20I0). Green marketing: a study of the impact of green marketing on consumer behavior in a period of recession. The Business Review, 16(I), I34-I40.

Peattie, K. (200I). Towards sustainability: the third age of green marketing. The Marketing Review, 2(Winter), I29-I46.

Popper, K. R. (1977). A lógica da pesquisa social. São Paulo: Editora Cultrix.

Rao, P., \& Holt, D. (2005). Do green supply chain lead to competitiveness and economic performance? USA: International Journal of Operations \& Production Management, 25(9), 898-916.

Shang, K., Lu, C., \& Li, S. (2010). A taxonomy of green supply chain management capability among electronics-related manufacturing firms in Taiwan. Journal of Environmental Management, $91(5)$, I218--1226. 
Smith, D., \& Langfield-Smith, K. (2004). Structural Equation Modeling in Management Accounting Research: Critical Analysis and Opportunities. Journal of Accounting Literature, 23, 49-86.

Sobel, M. E. (1982). Asymptotic intervals for indirect effects in structural equations models. In S. Leinhart (Ed.). Sociological methodology 23,(Vol. I3, pp.290-312). San Francisco: Jossey-Bass.

Srivastava, S. (2007). Green supply chain management: a state of the art literature review. USA: International Journal of Management Review, 9(I), 53-80.

Tenenhaus, M., Vinzi, V. E., Chatelin, Y., \& Lauro, C. (2005). Pls - Path Modeling. Computational Statistics \& Data Analysis, 48(I), I59-205.

Vachon, S., \& Klassen, R. D. (2006). Green project partnership in the supply chain: the case of the package printing industry. USA: Journal of Cleaner Production, 14(6/7), 66I-67I.

Vaz, H. (20I4). Cliente quer economia e sustentabilidade. São Paulo: OESP. Economia e Negócios, Edição Especial, I3 de abril de 20I4, p. H2.

Vrijhoef, R., Koskela, L. J., \& Howell, G. (200I). Understanding construction supply chains: an alternative interpretation. National University of Singapore: 9th International Group for Lean Construction Conference.

Wagner, M., Schaltegger, S., \& Wehrmeyer, W. (2002). The relationship between the environmental and economic performance of firms: what does theory propose and what does empirical evidence tell us? Greener Management International, 34, 95-II8.

Wetzels, M., Odekerken-Schröder, G., \& Van Oppen, C. (2009). Using PLS path modeling for assessing hierarchical construct models: guidelines and empirical illustration. USA: MIS Quarter$l y, 33(\mathrm{I})$, I77-I95.

Yudelson, J. (2006). Marketing green business. Guide for engineering, construction and architecture. Boca Raton, FL/USA: The Fairmont Press.

Zhang, J. (20I0). Green marketing strategy analysis of real estate based on low-carbon economy. International Journal of Business and Management, 5(12), 2010.

Zhu, Q., Sarkis, J., \& Geng, Y. (2005). Green supply chain management in China: pressures, practices and performance. International Journal of Operations and Production Management, 25(5), 449-468.

Zhu, Q., Geng, Y., Fujita, T., \& Hashimoto, S. (2010). Green supply chain management in leading manufacturers: Case studies in Japanese large companies. USA: Management Research News, 33(4), 380-392. 


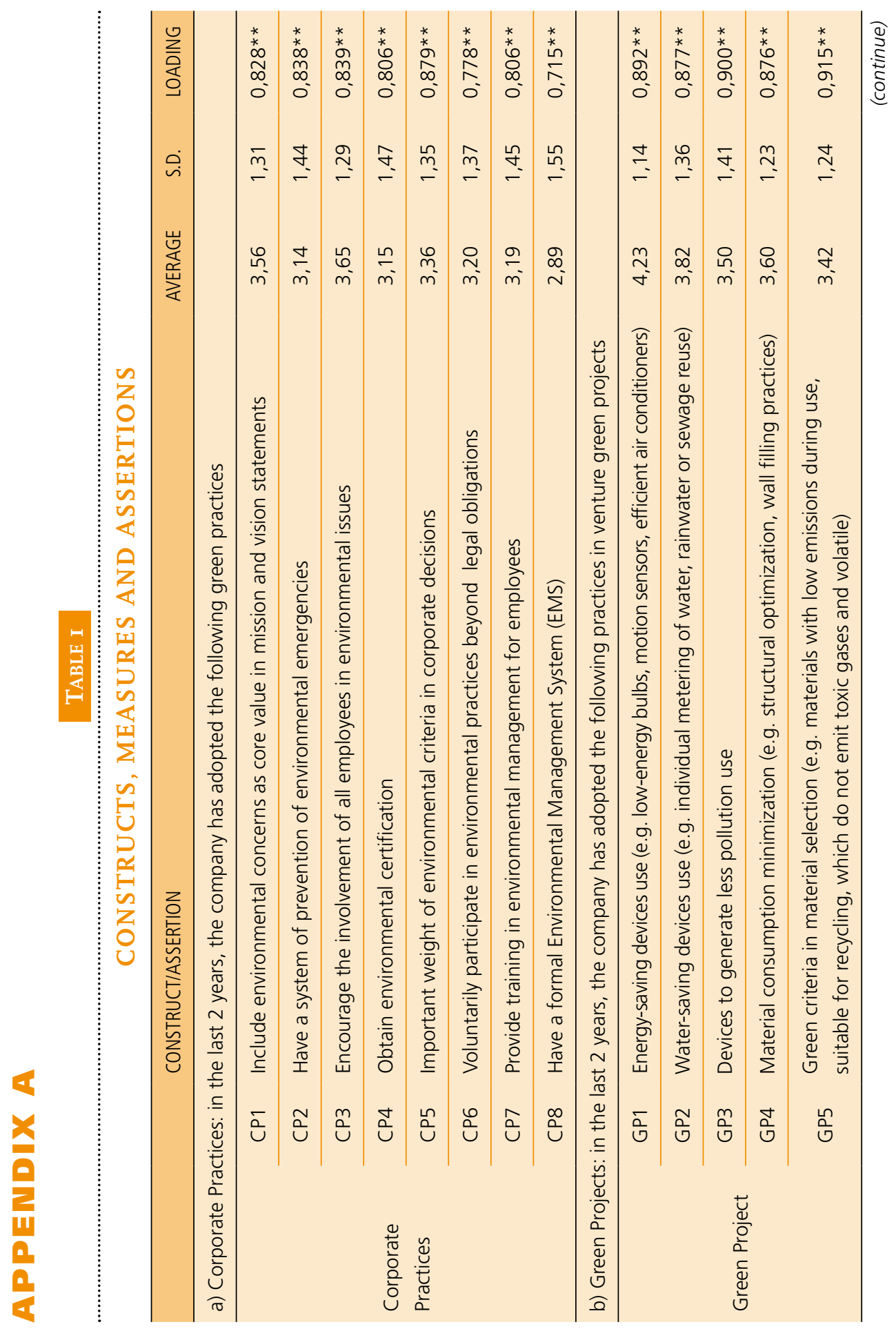




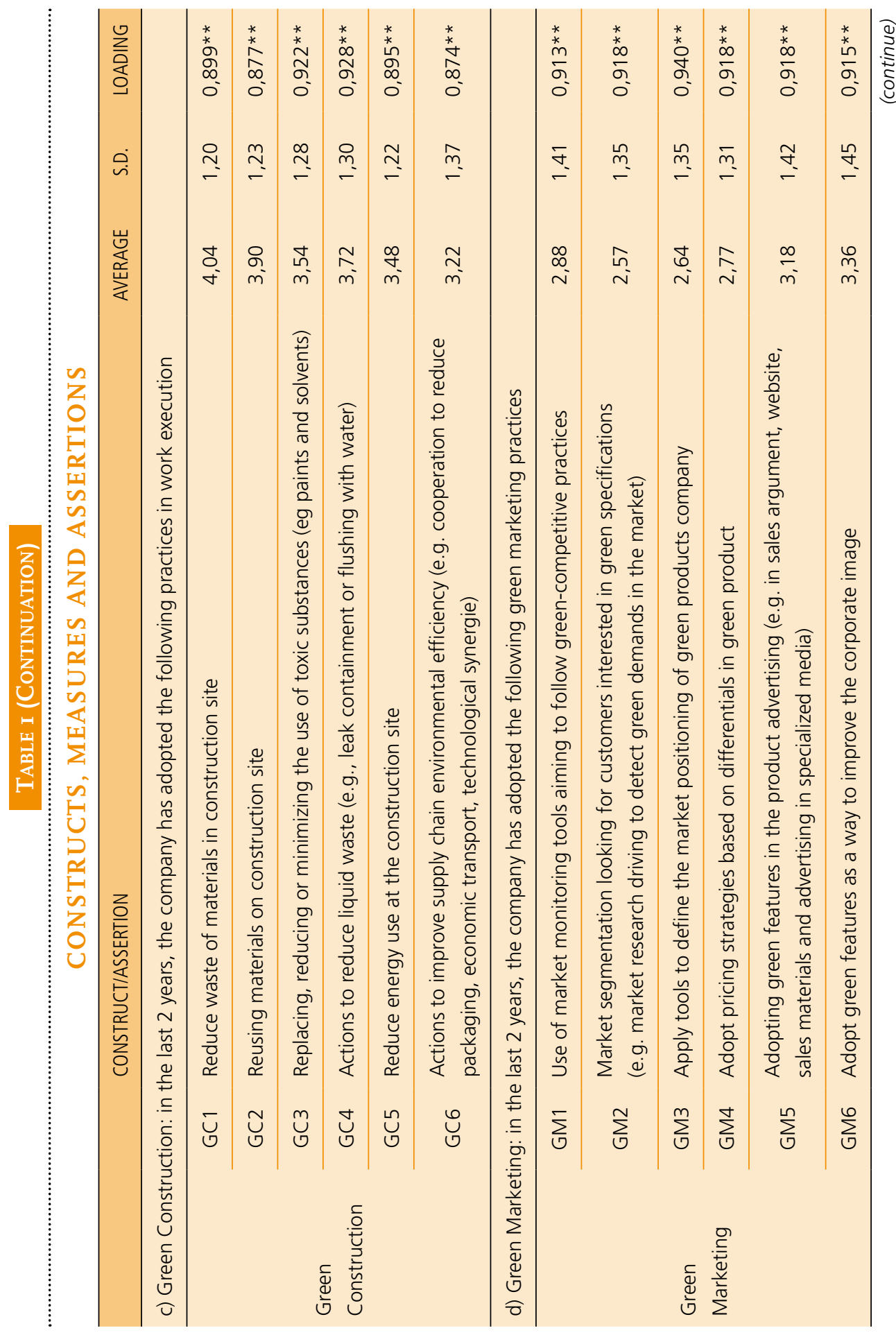




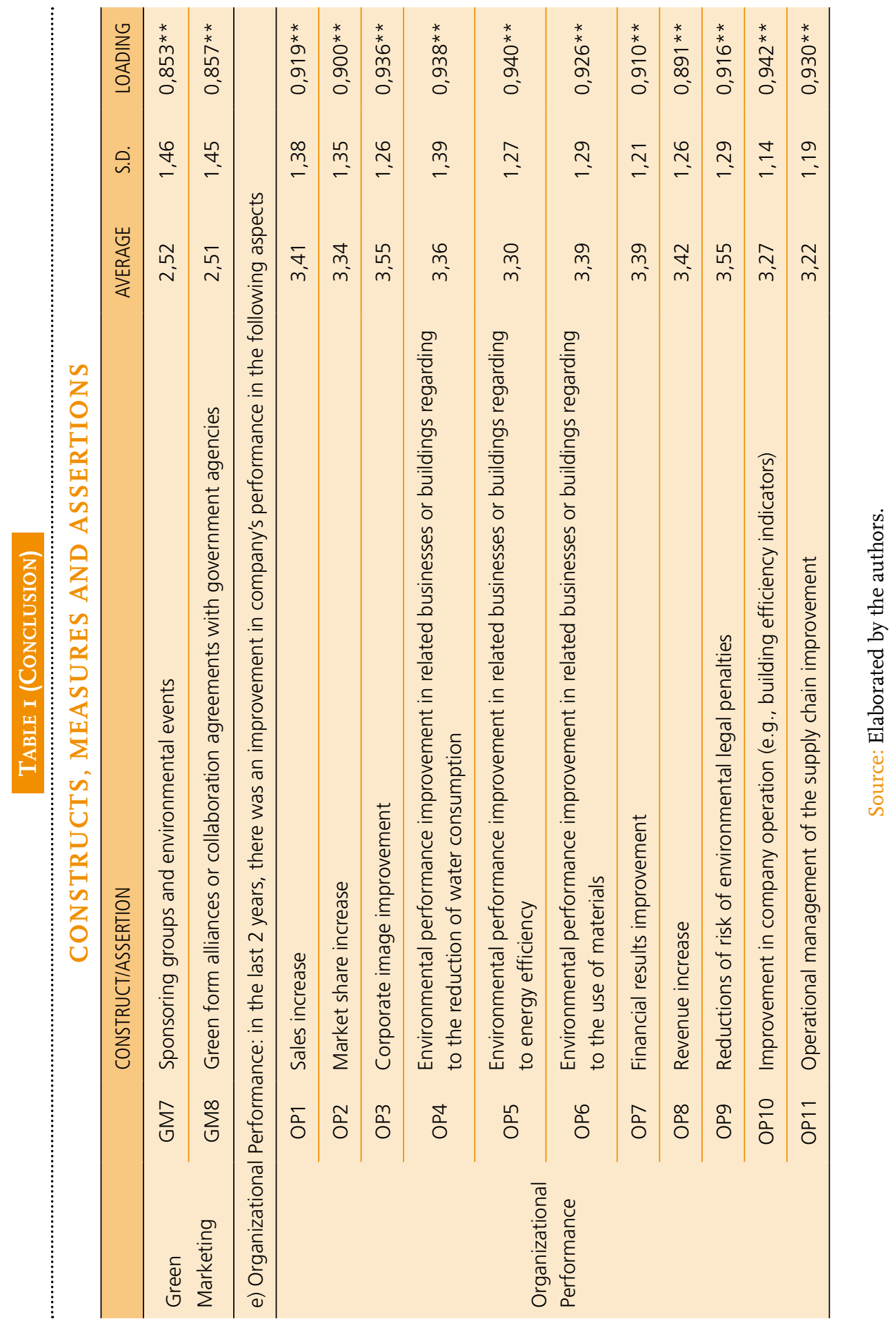

